\title{
INTERACTIONS OF AUXIN AND CYTOKININS IN REGULATING AXILLARY BUD FORMATION IN SUNFLOWER (Helianthus annuus L.)
}

Nagarathna, T.K. , Shadakshari, Y.G., Jagadish, K.S. and Sanjay, M.T.

All India Coordinated Research Projects on Sunflower, University of Agricultural Sciences, GKVK campus, Bangalore 560065, India

Received: April 01, 2009 Accepted: November 10, 2009

\begin{abstract}
SUMMARY
Sunflower is an important oilseed crop, known to grow a strong dominating single flower head. In recent times, axillary buds initiation and formation of multi flower heads is a common feature in many sunflower hybrids. To find out the reason for multi headedness an experiment was carried out in the hybrid KBSH-41. It was found that this trait is regulated by the interaction of environmental signals and plant growth regulators such as auxin and cytokinin. Any kind of stress induces the bud growth which affects the translocation of hormones in the transpiration system, especially auxin. When the translocation of basipetally moving auxin reduces, concentration of acropetally moving cytokinin increases leading to the development of axillary buds. When, under normal conditions, auxin to cytokinin ratio is not altered the plants develop single flower heads. The results of this study suggest that auxin has an inhibitory effect on the growth of axillary buds, while cytokinin promotes their growth. The mechanism of axillary bud growth depends on the ratio of these two hormones.
\end{abstract}

Key words: axillary buds, apical dominance, auxin, cytokinin, sunflower

\section{INTRODUCTION}

Apical dominance refers to the suppression of lateral bud growth by dominating main branch or shoot (Wilson, 2000). Apically derived auxin in the shoots is generally thought to control apical dominance. If the apical bud is removed, plants tend to grow several lateral buds, which may not be required for many crops. The degree of apical dominance over the lateral buds varies with plant species. Some plants such as sunflower exhibit strong apical dominance, causing the formation of single branchless shoots. Other plants like tomato have weak apical dominance allowing axillary bud growth and a bushy growth.

* Corresponding author: e-mail: rathnavijay06@rediffmail.com 
One hypothesis for the mechanisms of apical dominance is based on the competition of nutrients between centers of growth. According to this hypothesis, nutrients are preferentially transported to the apical bud, causing deficiency in the axillary buds. A second hypothesis for the mechanisms of apical dominance proposes that one or more plant hormones such as auxin, cytokinin and gibberellin act as correlative signals (Malladi and Burns, 2007).

The apical meristem present within the shoot apex is the source of basipetally moving auxin which inhibits lateral bud growth whereas cytokinin synthesized in root moves acropetally athe of intact apical meristem, auxin concentration is maintained throughout the plant system inhibiting lateral bud growth.

By decapitating plants and substituting various compounds for the apex, Thimann and Skoog (1934) demonstrated that apical dominance could be mediated by auxin. Thimann (1937) proposed that auxin synthesized in the shoot apex is transported basipetally down the stem to lateral buds, leading to growth inhibition.

Indole 3-acetic acid (IAA), the most abundant type of auxin in plants, is synthesized in quantity in the shoot apex and young growing leaves (Ljung et al., 2001). When the plant is decapitated, major source of auxin is removed. The auxin is transported basipetally down the shoot in a polar manner by active transport system in the vascular parenchyma (Blakeslee et al., 2005).

When IAA is added externally to the cut stem surface of sunflower, it moves into the existing cotyledons and partially inhibits their growth (Saks and Ilan, 1984). It can be inferred from this study that apical meristem of the stem controls the growth of lateral buds while auxin is the main plant growth hormone involved in maintaining apical bud growth.

Cytokinin is another plant growth hormone involved in lateral branching, having indirect effect unlike auxin. It moves acropetally through the transpiration system in the xylem (Chen et al., 1985; Nordstrim et al., 2004) and promotes bud growth by inducing cell division (Sachs and Thimann, 1967; Miguel et al., 1998).

Though the concentration of auxin is maintained throughout the plant, its level will be low at the lower buds of the plants (Leyser, 2005; Morris et al., 2001). At the lower end of the plants, due to a higher amount of available cytokinin, lower buds are activated (Emery et al., 1998). Hence, the lower the auxin concentration, the higher the cytokinin level. Thus, auxin seems to be the primary signal for maintenance of apical dominance whereas interaction between cytokinin and auxin initiates and maintains axillary bud growth (Dun et al., 2006).

According to investigations by numerous researchers, whenever the apical apex is removed or decapitated, apical dominance ceases and axillary buds start developing. In sunflower, even in the presence of intact apical bud, axillary buds may grow.

Though it is desirable to have multi heads in male parents for continued supply of pollen, it is rather an undesirable trait in hybrids as it is likely to affect the devel- 
opment of main head and hence the productivity. It has not been explained so far why and how these axillary buds are produced in most hybrids although loss of apical dominance is considered to be the prime reason for multiheadedness in plants. What combination of conditions results in the loss of apical dominance is also not clear yet. However, it has been reported elsewhere that axillary buds grow depending on the developmental program or in response to environmental cues. Some of the environmental cues reported to weaken the apical dominance are high irradiation, high wind velocity, $\mathrm{CO}_{2}$ and nutrients (Cline, 1996; Gregory and Veal, 1957; Anderson, 1976; Prasad and Cline, 1985a, b).

Keeping this in mind, this investigation was carried out to find a possible reason for axillary bud growth in sunflower.

\section{MATERIAL AND METHODS}

A hybrid KBSH-41 released from UAS, Bangalore, has been sown in kharif and rabi season for 2 years. This hybrid is known to be sensitive to axillary bud formation. The plants were grown in nine treatments and three replications in a randomized complete block design. The treatments included control where plants were grown with a full package of practices, nutrient stress coupled with early moisture stress (25 to 50 days after sowing, DAS) and late moisture stress (35-65 DAS), excess irrigation coupled with nutrient stress and excess nutrients with early moisture stress. For nutrient stress treatments, no fertilizers were applied, while the other treatments received a full package of fertilizers.

Plant growth hormones like auxin and cytokinin were estimated by bioassay. Plant material was collected in all the treatments at different stages. To estimate the hormones, plants were cut at each node of both plants with multi heads and mono heads. These samples were kept in petri plates containing $10 \mathrm{ml}$ methanol, to allow diffusion of auxin overnight. The diffused sap was then mixed thoroughly with double distilled water making up the volume of $10 \mathrm{ml}$. Further, auxin and cytokinin concentrations were quantified by cucumber root growth inhibition bioassay for auxins and cucumber cotyledon expansion bioassay for cytokinin.

Plant growth hormone estimation was also done in male parents with multi heads (R-298) and mono heads (6D-5-3-5), to check whether this particular trait is expressed in hybrids due to the presence of multi heads in the male parent.

Reducing sugar (glucose) was also estimated in the collected samples by dinitrosalicylic acid method (Thimmaiah, 1999). As explained earlier for growth hormone estimation, each node was cut and kept in $10 \mathrm{ml}$ ethanol. The diffusate was used for glucose estimation.

To test whether axillary buds grow only in hybrids because of its male parent, another experiment was conducted with both a variety (DRSF-108) and a hybrid (KBSH-44). The test plants were supplied with different fertilizer levels, control (C), no fertilizers, $50 \%$ of the recommended dose of fertilizers RDF (T1), 100\% RDF (T2) and 150\% RDF (T3). 
During the experimental period at regular intervals of time, the plants were examined for the presence or absence of buds. At the end of the experimental period, the number and percentage of plants exhibiting axillary buds and average numbers of buds in different treatments were computed.

\section{RESULTS AND DISCUSSION}

In rabi, percent of auxiliary buds observed was high in plants when they were exposed to early moisture stress (Table 1, treatments 3 and 5).

Table 1: Effect of stress on \% auxiliary buds in kharif and rabi seasons

\begin{tabular}{llcc}
\hline SI no. & Treatment & $\begin{array}{c}\text { \% auxiliary buds } \\
\text { in kharif }\end{array}$ & $\begin{array}{c}\text { \% auxiliary buds } \\
\text { in rabi }\end{array}$ \\
\hline 1 & Control & 7.50 & 12.66 \\
2 & Nutrient stress & 7.50 & 63.00 \\
3 & Early moisture stress (20-50 DAS) & 32.50 & 66.00 \\
4 & Late moisture stress (35-65DAS) & 11.65 & 56.00 \\
5 & Nutrient+Early moisture stress & 11.00 & 67.00 \\
6 & Excess irrigation & - & 25.00 \\
7 & Excess irrigation + Nutrient stress & - & 56.00 \\
8 & Excess nutrients & 2.50 & 26.00 \\
9 & Excess nutrients+Early moisture stress & - & 39.66 \\
\hline
\end{tabular}

Excess irrigation and application of double dose of fertilizers did not have much effect (treatments 6 and 8). Nutrient and moisture stress triggered bud growth. Buds were observed even in the control, wherein its percentage was less compared with the other treatments. Percent of auxiliary buds was low in kharif due to interrupted rainfall which affected the treatment imposition. Season also plays a role in bud growth, since the stress level will be high in rabi/summer.

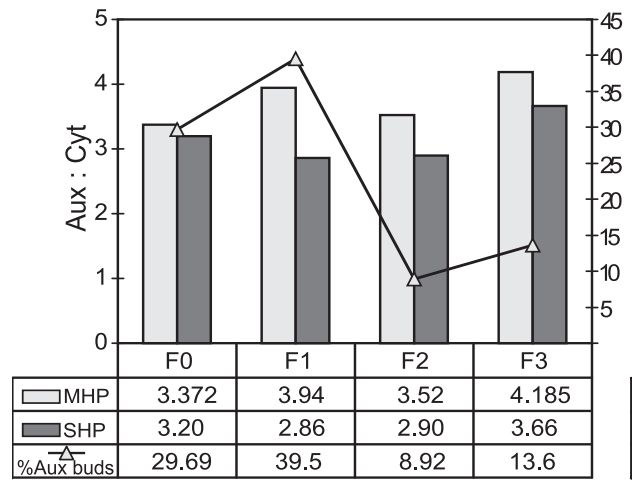

Figure 1a:Percent auxiliary buds and auxin to cytokinin ratio in the variety DRSF108 at different fertilizer levels

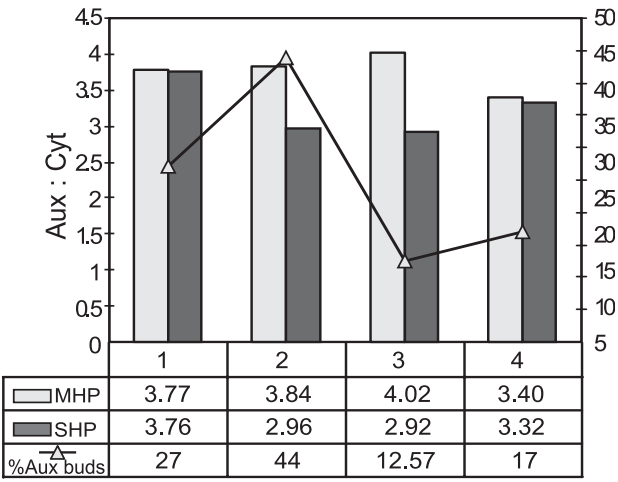

Figure 1b: Percent auxiliary buds and auxin to cytokinin ratio in the hybrid $\mathrm{KBSH}$ 44 at different fertilizer levels

To test whether this trait comes from the male parent of hybrid, the experiment was conducted with both a variety (DRSF 108) and a hybrid (KBSH-44) at different 
fertilizer level $(\mathrm{C}=$ Control, $\mathrm{T} 1=50 \% \mathrm{RDF}, \mathrm{T} 2=100 \% \mathrm{RDF}$ and $\mathrm{T} 3=150 \% \mathrm{RDF})$. Auxiliary buds were formed not only in the hybrid but also in the variety, indicating that this problem is not due to the male character of any hybrid. Auxin to cytokinin ratio was estimated. It was found to be higher in the plants with multi heads than in those with mono heads. There was no significant difference in their ratio between the variety and the hybrid (Figures $1 \mathrm{a}$ and $1 \mathrm{~b}$ ). Percent of auxiliary buds was high in the control where no fertilizer was applied and also in $\mathrm{T} 1$. These results indicate that nutrient stress triggered the auxiliary bud growth.

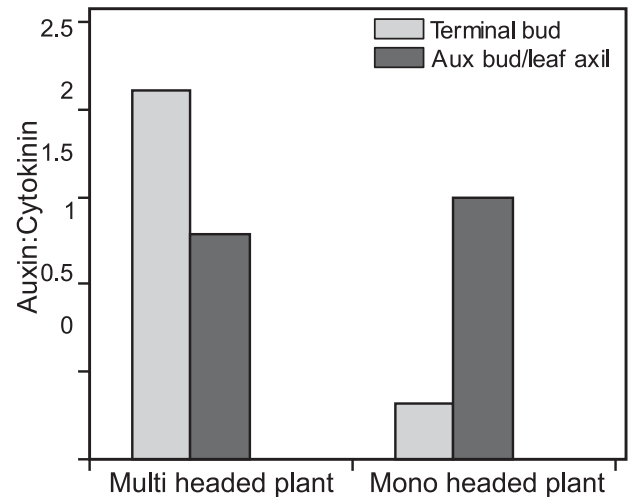

Figure 2: Auxin to cytokinin ratio during moisture stress in plants with mono heads and multi heads
In the present experiment, plant growth hormones like auxin and cytokinin were estimated by bioassay. Plant material was collected in all the treatments at different stages. To estimate the hormones, diffusion method was applied using methanol. Auxin (ug/bud) and cytokinin (ng/bud) were quantified. Reducing sugar, i.e., glucose (ug), was estimated by the dinitrosalicylic acid method.

Further, auxin and cytokinin contents were estimated in each node of the plants with multi heads and in leaf axils of the plants with mono heads.

The basipetally moving auxin content was found to be high in buds next to the main head, becoming lower towards the base of the plant. Its opposite is the acropetally moving cytokinin (Figures 2, 3a and $3 \mathrm{~b}$ ).

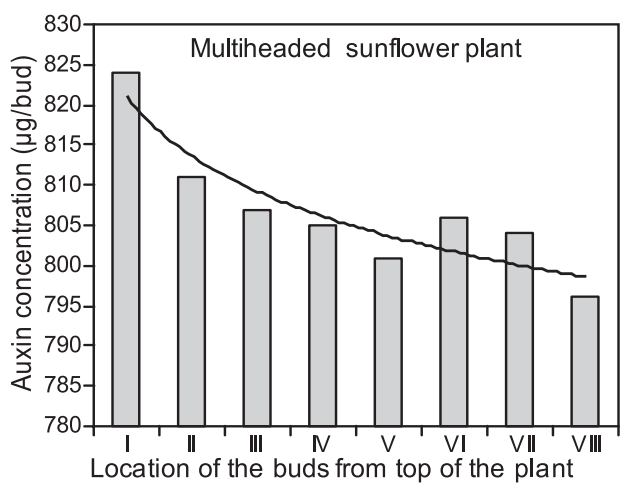

Figure 3a:Auxin content ( $\mu \mathrm{g} / \mathrm{bud}$ ) in different buds of sunflower plants with multi heads

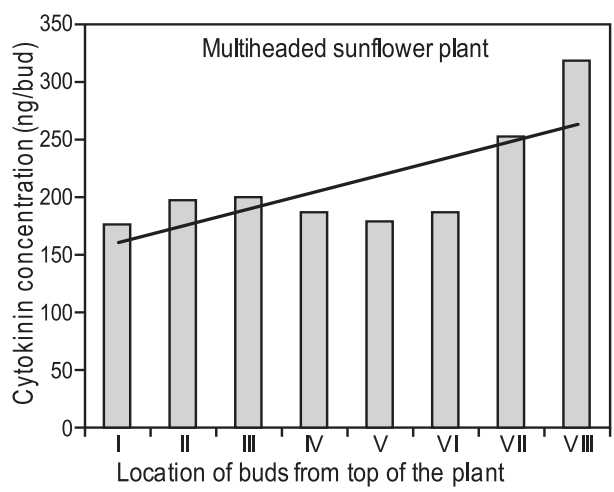

Figure 3b:Cytokinin content (ng/bud) in different buds of sunflower plants with mutli heads

Their ratio was not affected in leaf axils of those plants which did not produce auxiliary buds (Figures $4 \mathrm{a}$ and $4 \mathrm{~b}$ ). These results indicate that auxin concentration 
is maintained throughout the plant in mono headed plants, inhibiting bud growth. As long as dominant apical meristem remains intact, auxin will be transported down the stem.
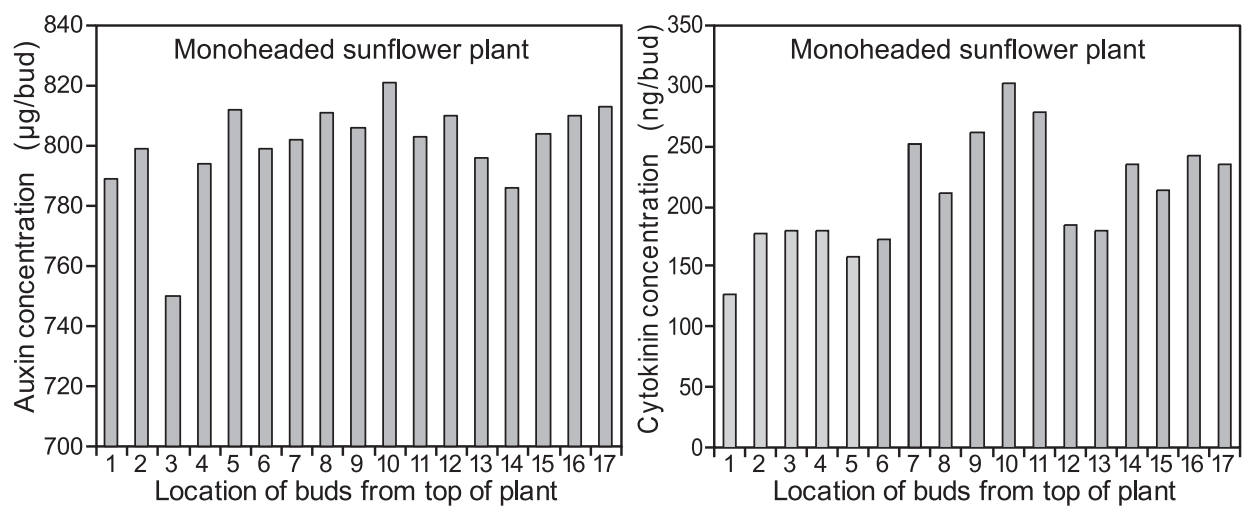

Figure 4a:Auxin concentration ( $\mu \mathrm{g} / \mathrm{bud})$ in different buds of sunflower plants with mono heads

Figure 4b:Cytokinin concentration ( $\mathrm{ng} / \mathrm{bud}$ ) in different bud

Growth hormones were estimated in very minute, just initiating buds at three different positions on the plant. The concentration of the hormones was higher in these buds than in mature buds, indicating that the change in the concentration of the hormones leads to the initiation of bud growth (Figure 5).

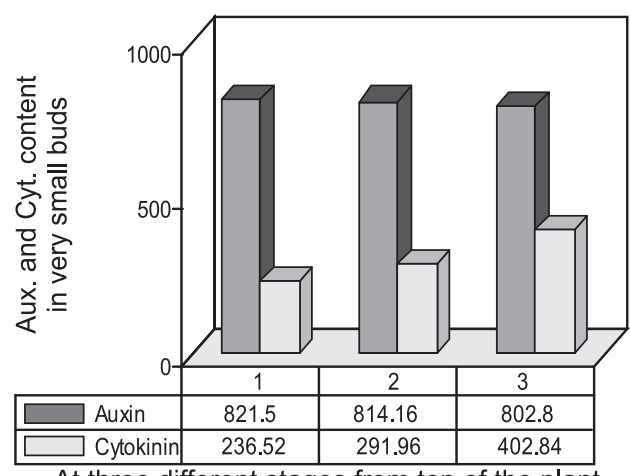

At three different stages from top of the plant

Figure 5: Auxin ( $\mu \mathrm{g} / \mathrm{bud})$ and cytokinin (ng/ bud) content in very small buds of sunflower plants with multi heads

In another experiment, apical bud was decapitated 65 days after sowing. Growth pattern of auxiliary bud formation was observed and compared with those plants which allowed auxiliary bud growth with their main head intact. The lowest buds on the stem were activated first in the presence of an intact apex as a result of the lower amount of auxin present and the rate of its degradation. At lower auxin levels, more cytokinin are available to initiate bud break at lower stem locations. In contrast, removal of apical bud caused a rapid reduction in auxin from top of the stem towards the base, causing lateral bud break.

Thus, auxin appears to be the primary signal communicating apical dominance, but cytokinin also interact with auxin to initiate and sustain auxiliary bud growth.

The multiple head trait being present in many male parents, auxin and cytokinin contents were estimated in R-lines with and without side branches or auxiliary buds. This was done to find whether the formation of auxiliary bud is expressed in 
hybrids due to the male parent. For this, two parental lines were selected, 6D-5-3-5, a mono headed male parent, and R-298, a multi headed male parent. The results showed that there was no change in auxin and cytokinin concentrations in either line, suggesting that this particular trait may not be a male characteristic (Table 2).

Table 2: Concentration of growth hormones in multi headed and single headed R-lines

\begin{tabular}{lcccc}
\hline \multirow{2}{*}{ Bud no. } & \multicolumn{2}{c}{$\begin{array}{c}\text { Concentration of growth hormones in multi } \\
\text { headed "R" line R-298 }\end{array}$} & $\begin{array}{c}\text { Concentration of growth hormones in mono } \\
\text { headed "R" line 6D-5-3-5 }\end{array}$ \\
\cline { 2 - 5 } & Auxin $(\mu \mathrm{g} / \mathrm{bud})$ & Cytokinin (ng/bud) & Auxin $(\mu \mathrm{g} / \mathrm{bud})$ & Cytokinin $(\mathrm{ng} / \mathrm{bud})$ \\
\hline 1 & 824 & 176 & 814 & 194 \\
2 & 811 & 231 & 897 & 139 \\
3 & 817 & 199 & 794 & 211 \\
4 & 805 & 187 & 794 & 176 \\
5 & 809 & 178 & 818 & 181 \\
6 & 806 & 188 & 786 & 185 \\
\hline
\end{tabular}

The glucose content was estimated by the dinitrosalicylic acid method. Higher glucose content ( $\mu \mathrm{g} / \mathrm{g}$ bud wt.) was observed in plants with multi heads (118.8 $\mu \mathrm{g} / \mathrm{g}$ ) than in plants with single heads $(77.5 \mu \mathrm{g} / \mathrm{g}$ ) (Figure 6). Glucose was also estimated in each axil. In almost all nodes, a relatively higher glucose content was observed in the multi headed plants (Figure 7). The plants may be synthesizing more photosynthates to meet the demand from the growing auxiliary buds.

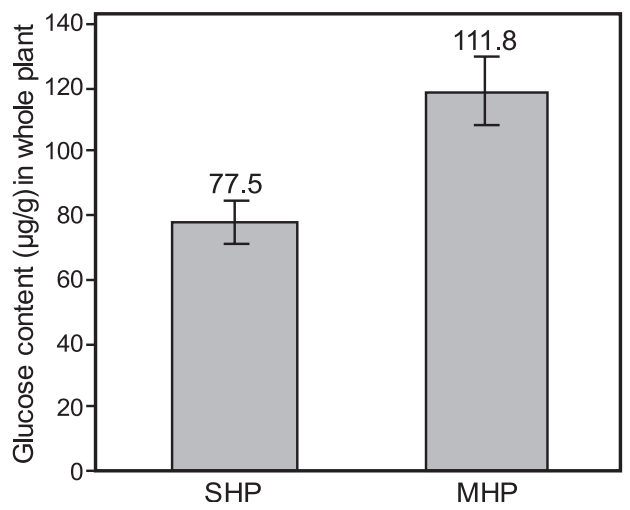

Figure 6: Total reducing sugar (glucose) in multi headed and single headed plants

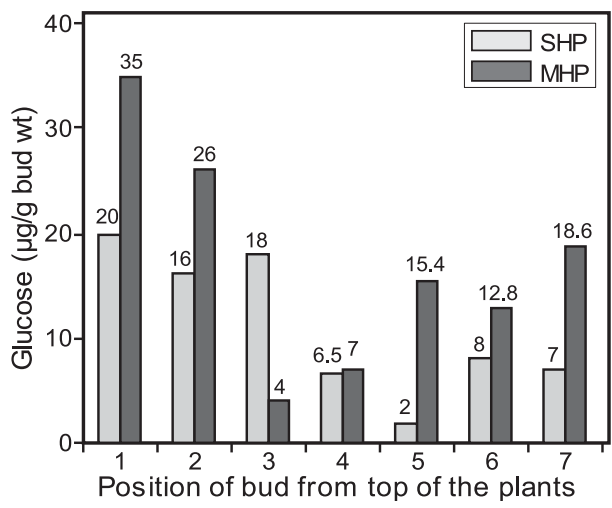

Figure 7: Glucose content in different buds from top of the multi headed and single headed plants

In the randomly selected 50 multi headed and single headed plants, total dry matter (TDM) and grain yield were estimated. There was no significant difference in grain yield whereas TDM in the multi headed plants was increased (Table 3). These results indicate that auxiliary bud growth increased only the TDM whereas it did not have any major effect on the grain yield. 
Table 3: Total dry matter $(\mathrm{g} / \mathrm{pl})$ and grain yield $(\mathrm{g} / \mathrm{pl})$ as affected by axillary buds in sunflower

\begin{tabular}{lcccc}
\hline & \multicolumn{2}{c}{ TDM $(\mathrm{g} / \mathrm{pl})$} & \multicolumn{2}{c}{ Grain yield $(\mathrm{g} / \mathrm{pl})$} \\
\cline { 2 - 5 } & $\begin{array}{c}\text { Multi headed } \\
\text { plants }\end{array}$ & $\begin{array}{c}\text { Single headed } \\
\text { plants }\end{array}$ & $\begin{array}{c}\text { Multi headed } \\
\text { plants }\end{array}$ & $\begin{array}{c}\text { Single headed } \\
\text { plants }\end{array}$ \\
\hline Mean & 105.98 & 64.50 & 33.8 & 34.69 \\
\hline SEm+ & & 7.42 & \multicolumn{2}{c}{3.72} \\
CD $(p=0.05)$ at $5 \%$ & 21.64 & \multicolumn{2}{c}{ NS } \\
CV\% & 43.00 & \multicolumn{2}{c}{54.34} \\
\hline
\end{tabular}

\section{CONCLUSIONS}

The auxin to cytokinin ratio changes in response to stress (Figure 5.3.3), affecting hormone translocation within the plant. This ratio is higher in plants with multi heads and lower in plants where only mono heads are produced. Auxin concentration in the transpiration system becomes reduced, as it is accumulated in the main bud. At lower auxin levels, more cytokinin is available to initiate bud break. Glucose was found to be high in plants with multi heads, indicating that during stress photosynthates synthesized by such plants will not translocate from the source (leaves) to the sink (the main head), diverting all photosynthates to produce small auxiliary buds.

These results support the theory that the auxin to cytokinin ratio might be the central factor controlling the growth of axillary buds and also that auxin is the primary signal inducing changes in the growth and development of axillary buds.

\section{REFERENCES}

Anderson, A.S., 1976. Regulation of apical dominance by ethephon, irradiance and $\mathrm{CO}_{2}$. Physiol. Plantarum 37: 303-308.

Bangerth, F., 1994. Response of cytokinin concentration in the xylem exudates of bean (Phaseolus vulgaris L.) plants to decapitation and auxin treatment, and relationship to apical dominance. Planta 194: 439-442.

Blakeslee, J.J., Peer, W.A., Murphy, A.S., 2005. Auxin transport. Current Opinion Pl. Bio. 8: 494-500.

Chen, C-M., Eru, J.R., Leisner, S.M., Chang, C-C., 1985. Localization of cytokinin biosynthetic sites in pea plants and carrot roots. Plant Physiol. 78: 510-513.

Cline, M.G., 1996. Exogenous auxin effects on lateral bud out growth in decapitated shoots. Annals of Botany 78(2): 255-266.

Dun, E.A., Ferguson, B.J., Beveridge, C.A., 2006. Apical dominance and shoot branching. Divergent opinions or divergent mechanisms? Plant Physiol. 142: 812-819.

Emety, R.J.N., Longnecker, N.E., Atkins, C.A., 1998. Branch development in Lupinus angustifolius L. II. Relationship with endogenous ABA, IAA and cytokinins in axillary and main stem buds. J. Exp. Bot. 49: 555-562.

Gregory, F.C., Veale, J.A., 1957. A reassessment of the problem of apical dominance. Symposia of Society of Experimental Biology. 11: 1-20.

Leyser, O., 2005. The fall and rise of apical dominance. Current Opinion in Genetics and Development. 15: 468-471.

Ljung, K., Bhalerao, R.P., Sanderberg, G., 2001. Sites and homeostatic control of auxin biosynthesis in Arabidopsis during vegetative growth. Plant J. 28: 465-474. 
Malladi, A., Burns, J.K., 2007. Communication by plant growth regulators in roots and shoots of horticultural crops. Hort. Science 42(5): 1113-1117.

Miguel, L.C., Longnecker, N.E., Ma, Q., Osborne, L., Atkins, C.A., 1998. Branch development in Lupinus angustifolius L. I. Not all branches have the same potential growth rate. J. Exp. Bot. 49: 547-553.

Morris, S.E., Turnbull, C.G.N., Murfet, I.C., Beveridge, C.A., 2001. Mutational analysis of branching in pea. Evidence that rms 1 and $r m s 5$ regulate the same novel signal. Plant Physiol. 126: 1205-1213.

Nordstrom, A., Tarkowski, P., Tarkowska, D., Norbaek, R., Astot, C., Dolezal, K., Sandberg, G., 2004. Auxin regulation of cytokinin biosynthesis in Arabidopsis thaliana: a factor of potential importance for auxin-cytokinin regulated development. Proc. Nat. Acad. Sci. USA 101: 677-684.

Prasad, T.K., Cline, M.G., 1985a. Mechanical perturbation-induced ethylene releases apical dominance in Pharbitis nil by restricting shoot growth. Plant Sci. 41: 217-222.

Prasad, T.K., Cline, M.G., 1985b. Gravistimulus direction, ethylene production and shoot elongation in the release of apical dominance in Pharbitis nil. J. Exp. Bot. 36: 1969-1975.

Sachs, T., Thimann, K., 1967. The role of auxins and cytokinins in the release of buds from dominance. Amer. J. Bot. 54(1): 136-144.

Saks, Y., Ilan, I., 1984. Hormone-mediated regulative action of the sunflower shoot apex on growth and cation level in the cotyledons - an additional manifestation of apical control. Plant Physiol. 74: 408-412.

Thimann, K.V., Skoog, F., 1934. On the inhibition of bud development and other functions of growth substances in Vicia faba. Proccedings of the Royal Society of London, Series B. 114: 317-339.

Thimann, K.V., 1977. On the nature of inhibition caused by auxin. Amer. J. Bot. 24: 407-412.

Thimmaiah, S.K., 1999. Carbohydrates. In: Standard methods for biochemical analysis. Kalyani publishers, New Delhi, India. pp 55-57.

Wilson, B., 2000. Apical control of branch growth and angle in woody plants. Amer. J. Bot. 87: 601-607.

\title{
INTERACCIÓN ENTRE AUXINAS Y CITOGUININAS EN LA REGULACIÓN DE LA FORMACIÓN DE YEMAS AXILARES
}

\author{
RESUMEN
}

El girasol es un cultivo oleaginoso importante cuya planta posee una inflorescencia única y dominante. Es común, en los últimos tiempos, el inicio de yemas axilares y la aparición de plantas policéfalas en muchos híbridos de girasol. Para averiguar el motivo de esta policefalía, se llevó a cabo un experimento con el híbrido KBSH-41. Se constató que este carácter se encuentra regulado por la interacción entre las señales del ambiente y los reguladores del crecimiento en las plantas, como las auxinas y citoquininas. Cualquier tipo de estrés induce el crecimiento de la yema, lo cual afecta la translocación de hormonas, especialmente las auxinas, durante la transpiración. Cuando se reduce la translocación basipetala de las auxinas, concentración acropetala de las citoquininas aumenta lo que permite el desarrollo de las yemas axilares. En condiciones normales, la relación auxina/citoquinina no se alteró y las plantas desarrollaron un único capítulo. Los resultados de este estudio sugieren que las auxinas tienen un efecto inhibitorio sobre el crecimiento de yemas axilares, mientras que las citoquininas lo promueven. El mecanismo de crecimiento de las yemas axilares depende de la relación entre estas dos hormonas. 


\title{
INTERACTIONS ENTRE AUXINE ET CYTOKININES POUR LA RÉGULATION DE LA FORMATION DE BOURGEONS AXILLAIRES CHEZ LE TOURNESOL (Helianthus annuus L.)
}

\author{
RÉSUMÉ
}

Le tournesol se caractérise habituellement par une floraison de type monocapitée. Récemment, l'initiation de bourgeons axillaires puis la formation de multiples capitules est devenue un caractère commun à plusieurs hybrides de tournesol.

Pour trouver une explication à l'intérêt des tournesols multi-capitules, une expérience a été menée sur l'hybride KBSH-41. Il a été constaté que ce facteur est régulé par l'interaction entre des signaux environnementaux et des hormones de croissance de la plante, telles que l'auxine et les cytokinines.

Tout type de stress provoque la croissance des bourgeons, ce qui affecte la translocation des hormones impliquées dans le processus de transpiration et particulièrement l'auxine. Lorsque la translocation de l'auxine en mouvement depuis l'apex jusqu'à la base diminue, la concentration en cytokinine en déplacement de la base vers l'apex augmente, entraînant un développement des bourgeons axillaires.

Par contre, le ratio auxine/cytokinine n'est pas altéré dans des conditions normales de développement conduisant à une fleur unique.

Les résultats de cette étude suggèrent que l'auxine a un effet inhibiteur sur la croissance des bourgeons axillaires, alors que la cytokinine la favorise. Le mécanisme de croissance des bourgeons axillaires dépend du rapport entre ces deux hormones. 